Wojciech RETKIEWICZ

Uniwersytet Łódzki

\title{
PRZESTRZEŃ INTERNETU W TURYSTYCE
}

\section{Wstęp}

Internet obecny jest $\mathrm{w}$ naszym życiu już od ponad 20 lat. W początkowym okresie jego dostępność była ograniczona głównie do środowiska akademickiego, jednakże już od drugiej połowy lat 90. XX w. liczba prywatnych użytkowników sieci zaczęła szybko wzrastać. W kolejnych latach wzrostowi ilościowemu towarzyszyły istotne zmiany jakościowe związane z rosnącą dostępnością przestrzenną Internetu, a także rozwijającymi się nowymi usługami i technologiami sieciowymi. Spośród nich szczególna rola przypadła specyfikacji języka HTML, pozwalającej na tworzenie światowego systemu dostępu do informacji w postaci serwisów WWW.

Łatwość zamieszczania na stronach internetowych treści zawierających przekaz w postaci nie tylko tekstu, ale także obrazu, dźwięku, a w następnych latach animacji komputerowych i filmów, oraz możliwość przechodzenia z jednej strony internetowej na drugą przy użyciu połączeń hipertekstowych spowodowała, że poza środowiskiem naukowym Internet stał się coraz powszechniej wykorzystywany do zastosowań komercyjnych, rozrywkowych i innych. 
W niniejszej pracy, w oparciu o przykłady pochodzące z Polski, autor chciałby wskazać na niektóre możliwości, jakie stwarza przestrzeń Internetu $\mathrm{w}$ zastosowaniach związanych z turystyką. Z oczywistych względów nie jest to wyczerpujące opracowanie, lecz ukazuje pewne tendencje związane $\mathrm{z}$ rozwojem coraz to nowszych technologii cyfrowych i ich implementacji w praktyce.

Ilustrując sposoby wykorzystania Internetu w turystyce autor proponuje odbycie swoistej podróży w czasie, zaglądając m.in. do popularnych w Polsce internetowych serwisów WWW.

\section{WWW w turystyce}

Pierwsza polska strona WWW pojawiła się w Internecie w roku 1993. W połowie 1996 r. zapoczątkował swoją działalność, istniejący do dziś, pierwszy polski portal informacyjny "Onet.pl" We wstępnej wersji stanowił on głównie zbiór odnośników do różnych, pogrupowanych tematycznie, stron WWW. W istniejącym archiwum zasobów Internetu można odtworzyć najstarszą zachowaną treść serwisu z 20 lutego 1997 r. Jej zawartość z tego okresu przedstawia rys. 1.

Jak widać, już wówczas Internet wykorzystywany był w szeroko rozumianej turystyce. Wśród zbioru odnośników występuje kategoria Turystyka, z widocznymi podkategoriami: Parki, Baza noclegowa i Ciekawe miejsca. Faktycznie liczba podkategorii jest większa i obejmuje ponadto takie, jak: Kluby i organizacje turystyczne, Agencje, Biura Podróży, Przewoźnicy, Przewodniki, Propozycje wycieczek, Trasy rowerowe.

W ówczesnym czasie liczba stron WWW była niewspółmiernie mniejsza niż obecnie, stąd tworząc zbiory odnośników twórcy serwisów starali się zgromadzić praktycznie kompletne zestawienia dostępnych stron. Dla przykładu, w prezentowanym wykazie znajduje się 10 odnośników do stron internetowych biur podróży. Między innymi jest to "Orbis”, którego witryna była jeszcze we wczesnej fazie tworzenia i nie dostarczała zbyt wielu informacji (rys. 2).

Pod koniec lat 90. XX w. większość stron firmowych stanowiła rodzaj wizytówki, przypominającej wcześniejsze reklamy prasowe, i wykorzystywała jedynie podstawowe możliwości, jakie stwarzał język HTML (tekst i prosta 


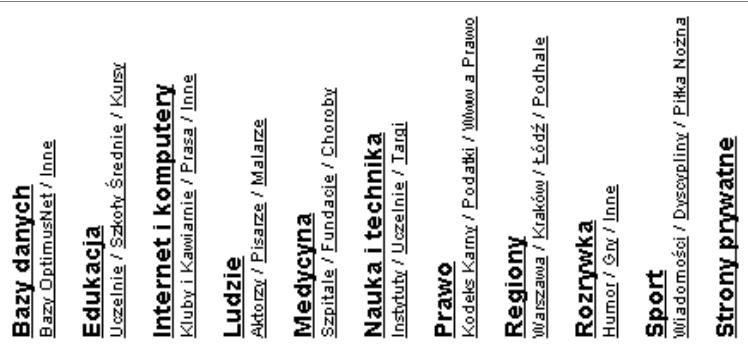
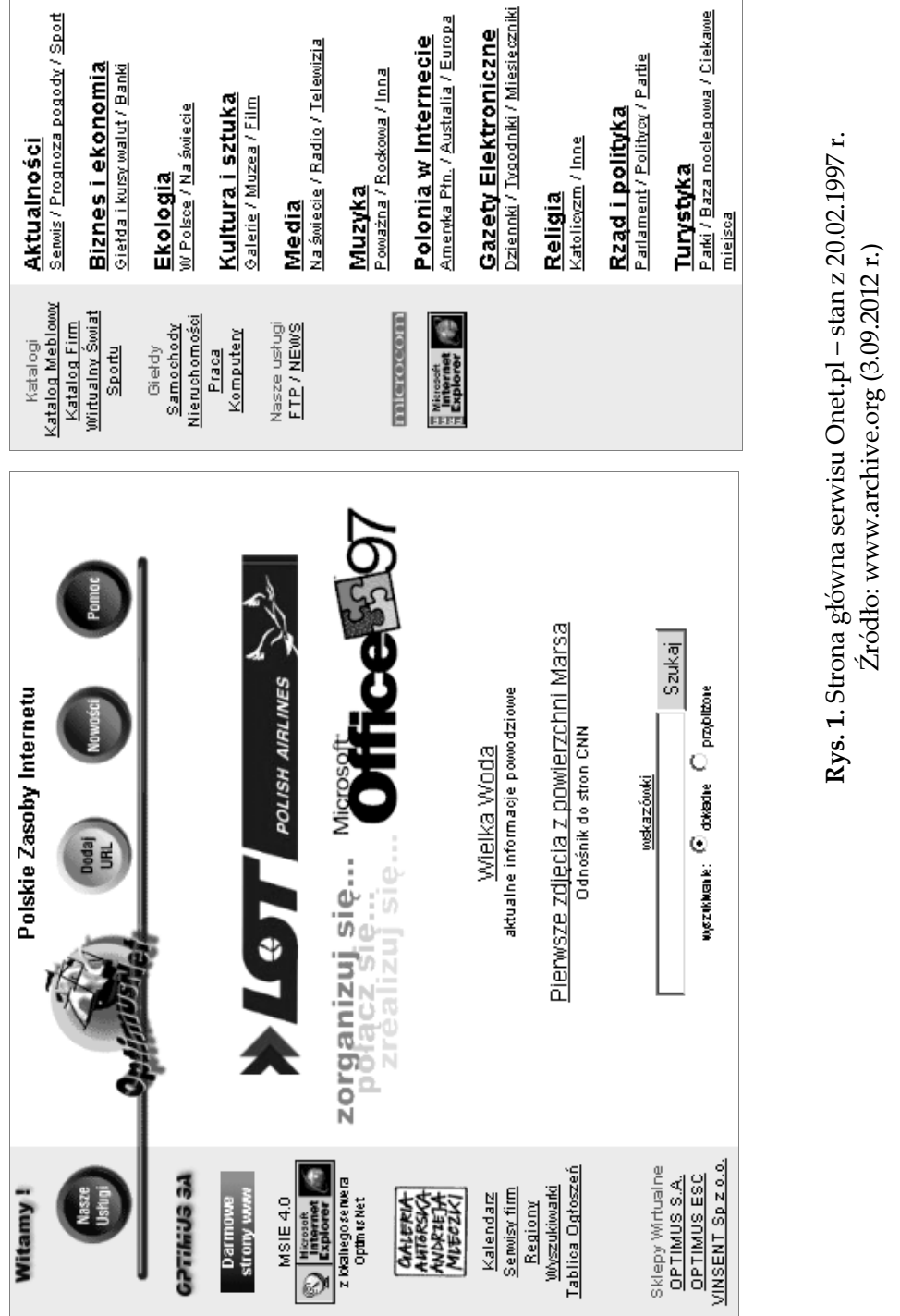

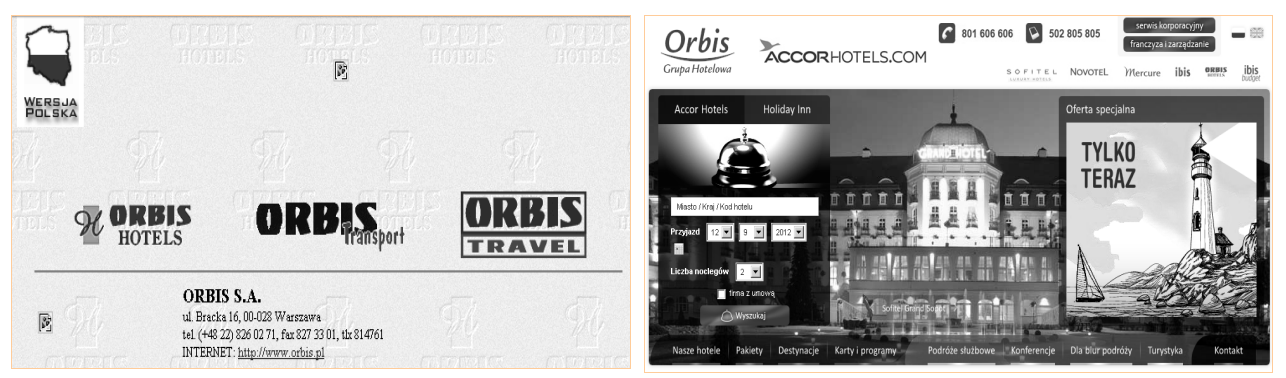

Rys. 2. Strona internetowa należąca do Orbis SA po lewej stronie - w 1997 r., po prawej w 2012 r. Źródło: www.archive.org (3.09.2012 r.)

grafika). Szybko jednak, dzięki rozszerzaniu specyfikacji języka HTML oraz zastosowaniu programowania treści stron $\mathrm{z}$ wykorzystaniem JavaScript i PHP, serwisy WWW zaczęły wyglądać coraz efektowniej, wzbogacając się $\mathrm{w}$ rozbudowaną grafikę i proste przekazy multimedialne (rys. 3).

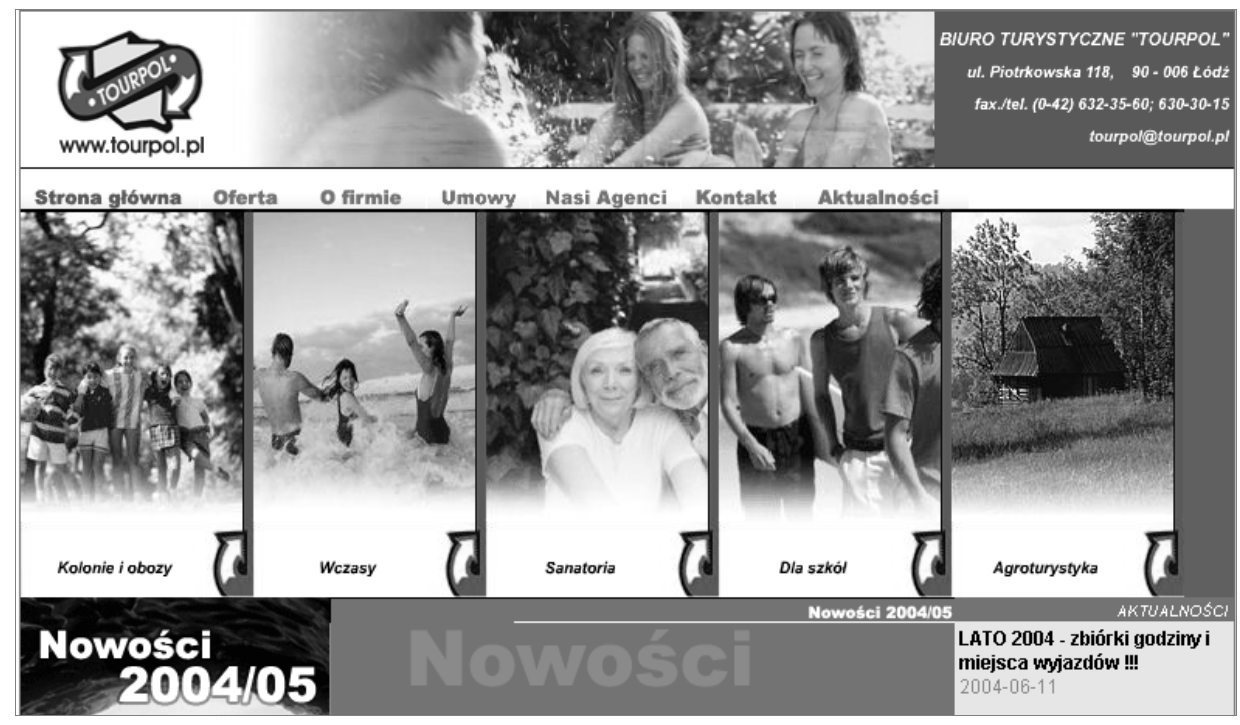

Rys. 3. Wygląd witryny WWW biura Tourpol z Łodzi - stan w roku 2004 Źródło: www.archive.org (3.09.2012 r.)

Możliwość prezentacji na stronach WWW wielu zdjęć, wzbogaconych opisem, a niekiedy także dźwiękiem (komentarz lub podkład muzyczny), 
stała się idealnym sposobem do prezentowania ofert biur podróży, hoteli, jak również w promowaniu regionów turystycznych. Sprzyjał temu także wzrost przepustowości łączy internetowych pozwalający na przesyłanie większej ilości danych. Kolejnym krokiem było uzupełnienie tradycyjnych zdjęć widokami panoramicznymi pozwalającymi odwiedzającym serwisy internetowe na oglądanie prezentowanych obiektów $\mathrm{z}$ różnych ujęć. $\mathrm{W}$ sieci pojawiły się wyspecjalizowane firmy świadczące tego typu usługi, oferujące zarówno wykonanie odpowiednich zdjęć, jak też ich udostępnianie w Internecie. Jako przykład wymienić można serwis www.panoramy360.pl (rys. 4).

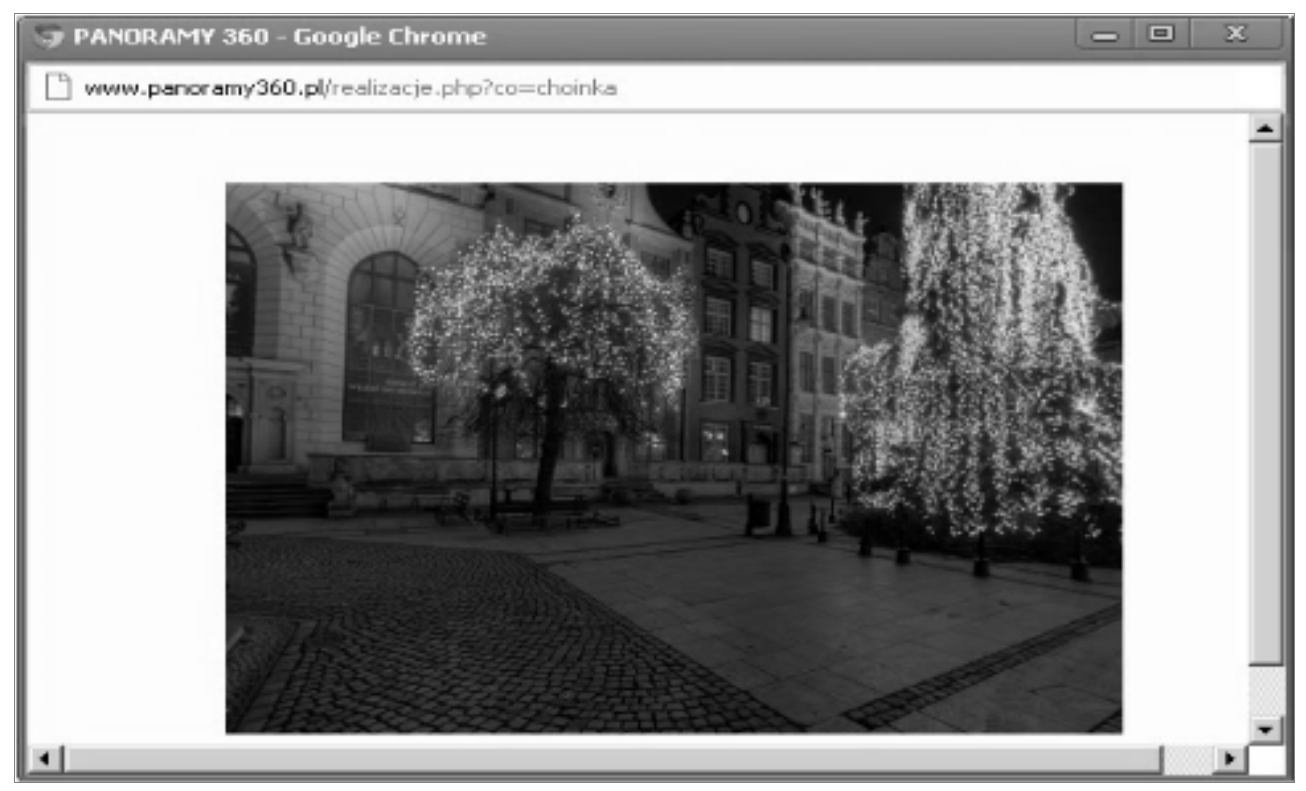

Rys. 4. Panorama starówki w Gdańsku zrealizowana przez www360.pl Źródło: www.panoramy360.pl (3.09.2012 r.)

\section{Internetowe usługi komunikacyjne}

Prawie od samego początku istnienia Internet odgrywał również rolę środka komunikacji. Poczta elektroniczna była jedną z pierwszych usług, która wykorzystywana była powszechnie przez użytkowników sieci. Ta forma kon- 
taktu wykorzystywana była również pomiędzy firmami turystycznymi i ich klientami. Poza wieloma zaletami, korzystanie z poczty elektronicznej nie pozwala jednak na wymianę informacji w czasie rzeczywistym. Taką formą komunikacji za pośrednictwem Internetu jest IRC (tzw. Chat) oraz rozwinięte w oparciu o nią liczne komunikatory (ICQ, GG, Tlen i inne).

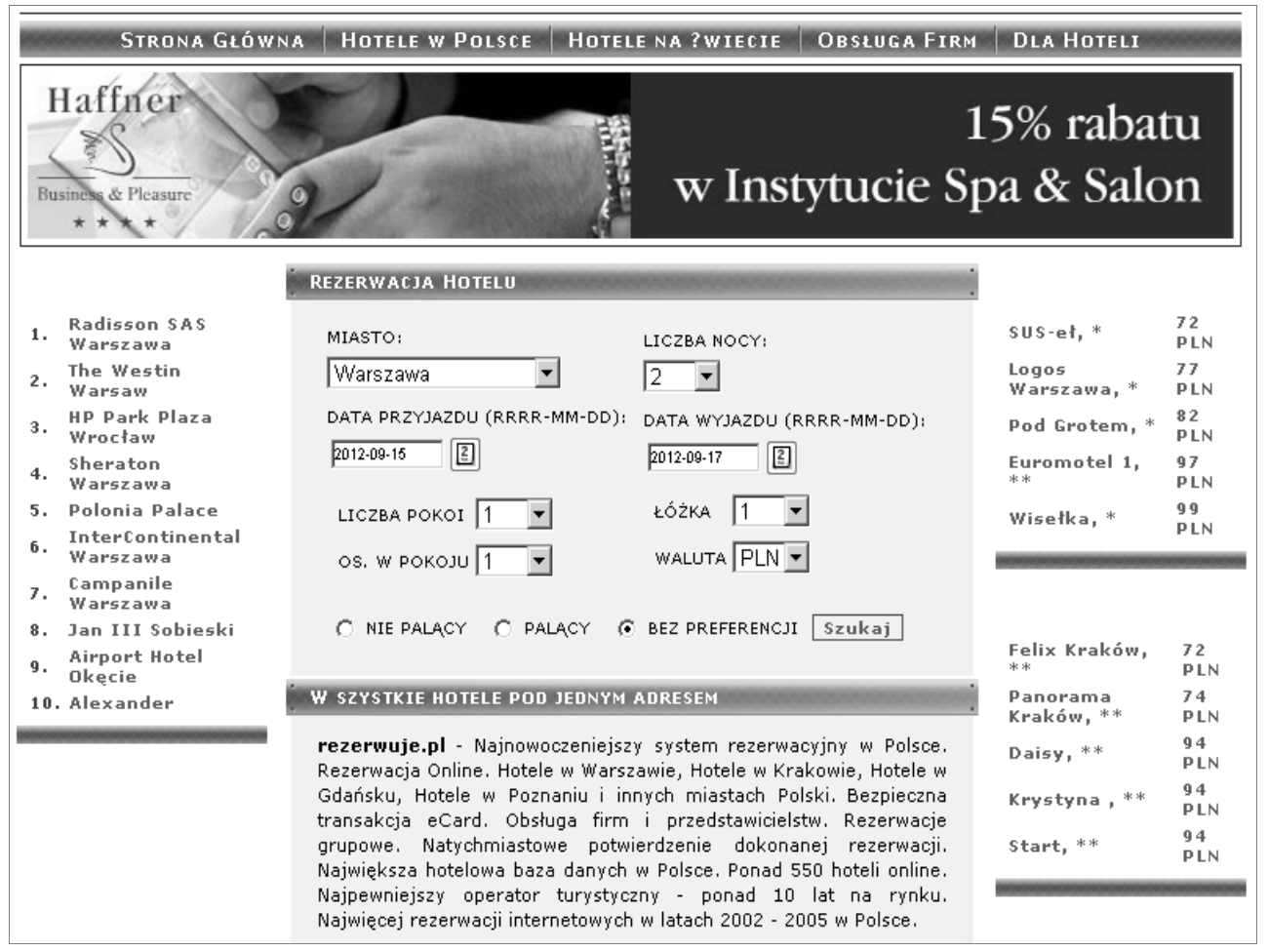

Rys. 5. Formularz do rezerwacji noclegów w hotelach - serwis rezerwuje.pl Źródło: www.rezerwuje.pl (5.09.2012 r.)

Aby ułatwić i przyspieszyć komunikację na wielu stronach należących do firm turystycznych zaczęto umieszczać także formularze, umożliwiające zarówno przekazywanie zapytań dotyczących oferty, jak i dokonywanie za ich pomocą rezerwacji, a nawet zakupu poszczególnych usług turystycznych. Sprzyjał temu rozwijający się równolegle sektor bankowości internetowej pozwalający na dokonywanie płatności on-line. 
W celu zilustrowania tego zagadnienia przedstawiono wygląd strony serwisu rezerwuje.pl pozwalającego na znalezienie najkorzystniejszej oferty noclegowej $\mathrm{w}$ hotelach $\mathrm{w}$ Polsce i za granica, $\mathrm{z}$ możliwością natychmiastowego zakupu usługi poprzez Internet (rys. 5).

\section{Strumieniowy przekaz obrazu}

Wzrost przepustowości łączy internetowych w połowie pierwszej dekady XXI w. pozwolił na znaczne zwiększenie ilości przesyłanych danych. W konsekwencji na stronach WWW poza tekstem, obrazami i dźwiękiem dostępne zaczęły być także filmy, w tym z kamer pracujących w trybie on-line, przekazujących obraz w czasie rzeczywistym. Możliwość ta znalazła dość szybko zastosowanie $\mathrm{w}$ dziedzinach związanych $\mathrm{z}$ turystyką m.in. $\mathrm{w}$ celu lepszej prezentacji oferty biur podróży, a także jako sposób promocji miejscowości i regionów turystycznych. Kamery on-line dały także turystom możliwość zapoznania się $\mathrm{z}$ aktualną $\mathrm{np}$. sytuacją pogodową $\mathrm{w}$ rejonie planowanego wyjazdu, warunkami drogowymi. Pozwalały też na samodzielne przekonanie się do walorów różnych miejsc na świecie mogących stanowić cel podróży. Poza odnośnikami do obrazu z kamer, które można znaleźć np. na stronach poszczególnych serwisów biur turystycznych, właścicieli obiektów czy też organizacji samorządowych, w sieci pojawiły się również liczne serwisy gromadzące odnośniki do widoków z kamer internetowych rozmieszczonych $\mathrm{w}$ różnych miejscach na świecie. Dla przykładu, $\mathrm{w}$ serwisie world cam.pl w roku 2006 znajdowało się 1650 odnośników do kamer przekazujących obraz on-line, z których 251 zlokalizowanych było w Polsce. W roku 2012 liczba zgromadzonych odnośników przekroczyła 6 tys., w tym ponad 1 tys. z Polski (rys. 6).

Część z dostępnych kamer wyposażona została w mechanizm sterujący, który może być obsługiwany przez osoby oglądające przekaz filmowy za pośrednictwem przeglądarek stron WWW. Pozwala to na samodzielne skierowanie obiektywu kamery na interesujące obiekty, jak również oglądanie szczegółów poprzez przybliżanie obrazu. 


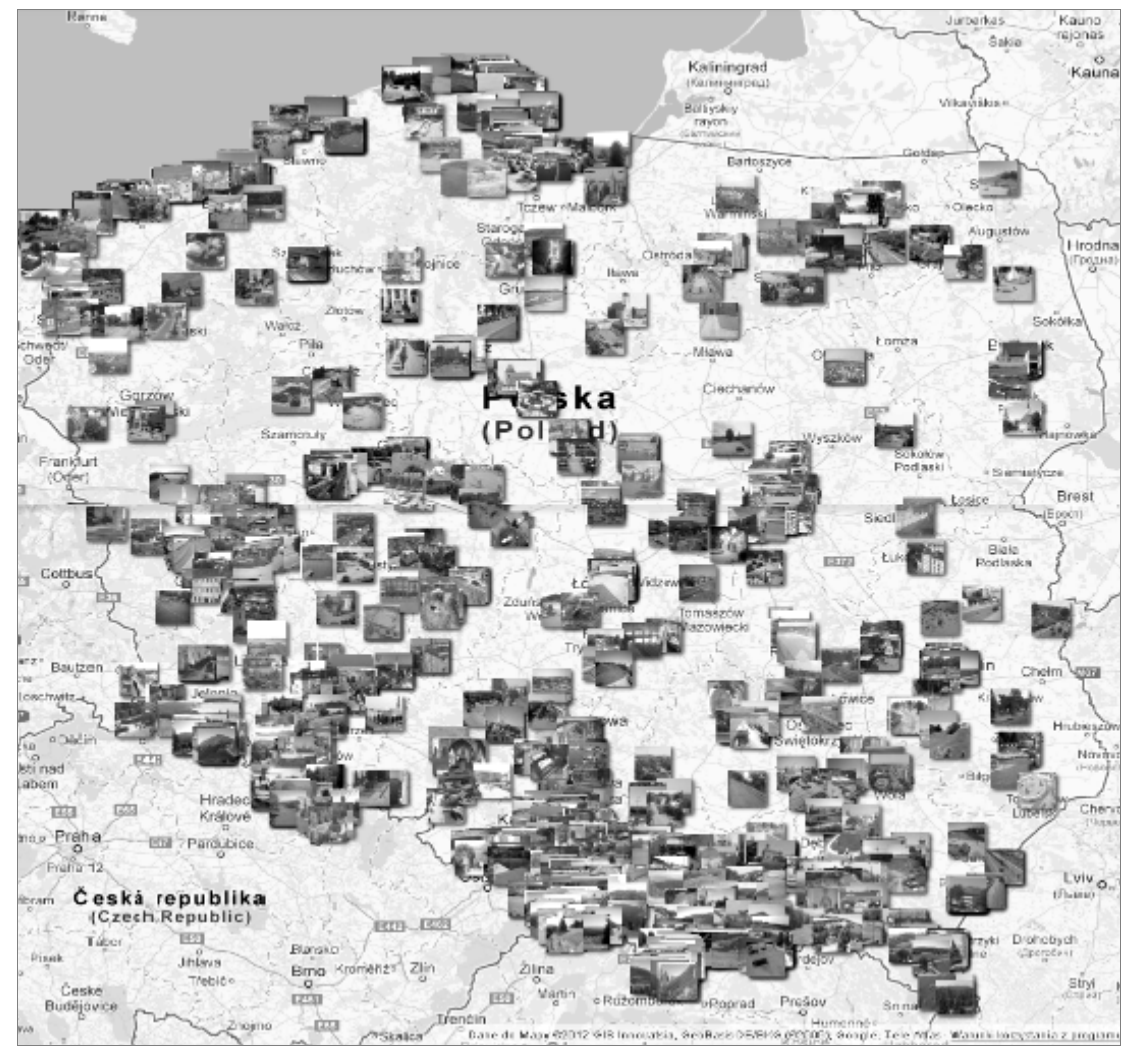

Rys. 6. Rozmieszenie kamer internetowych w Polsce dostępnych w serwisie worldcam.pl Źródło: www.worldcam.pl (5.09.2013 r.)

Zwiększenie interaktywności w przekazie informacji za pośrednictwem stron WWW spowodowało, że coraz częściej osoby odwiedzające serwisy mogły samodzielnie dostosowywać sposób zapoznawania się z treściami witryn do własnych upodobań.

\section{Wirtualne wycieczki}

W dziedzinach związanych z turystyką pojawiła się nowa forma prezentacji obiektów lub walorów turystycznych określana jako wirtualne zwiedzanie lub też wirtualne wycieczki. 
Poprzez odpowiednie przygotowywanie wielu zdjęć panoramicznych i połączenie ich specjalnym skryptem programowym, obsługiwanym przez przeglądarki WWW, użytkownik zyskał możliwość swobodnego „przemieszczania się" w obrębie prezentowanej przestrzeni i oglądania obiektów $\mathrm{z}$ dowolnych stron. $\mathrm{W}$ ten sposób możliwa stała się prezentacja $\mathrm{np}$. oferty hotelowej czy „zwiedzanie” muzeów i galerii. W podobny sposób można dziś zapoznać się z zabytkami w wielu miastach oraz dotrzeć do często bardzo egzotycznych i trudno dostępnych miejsc na świecie.

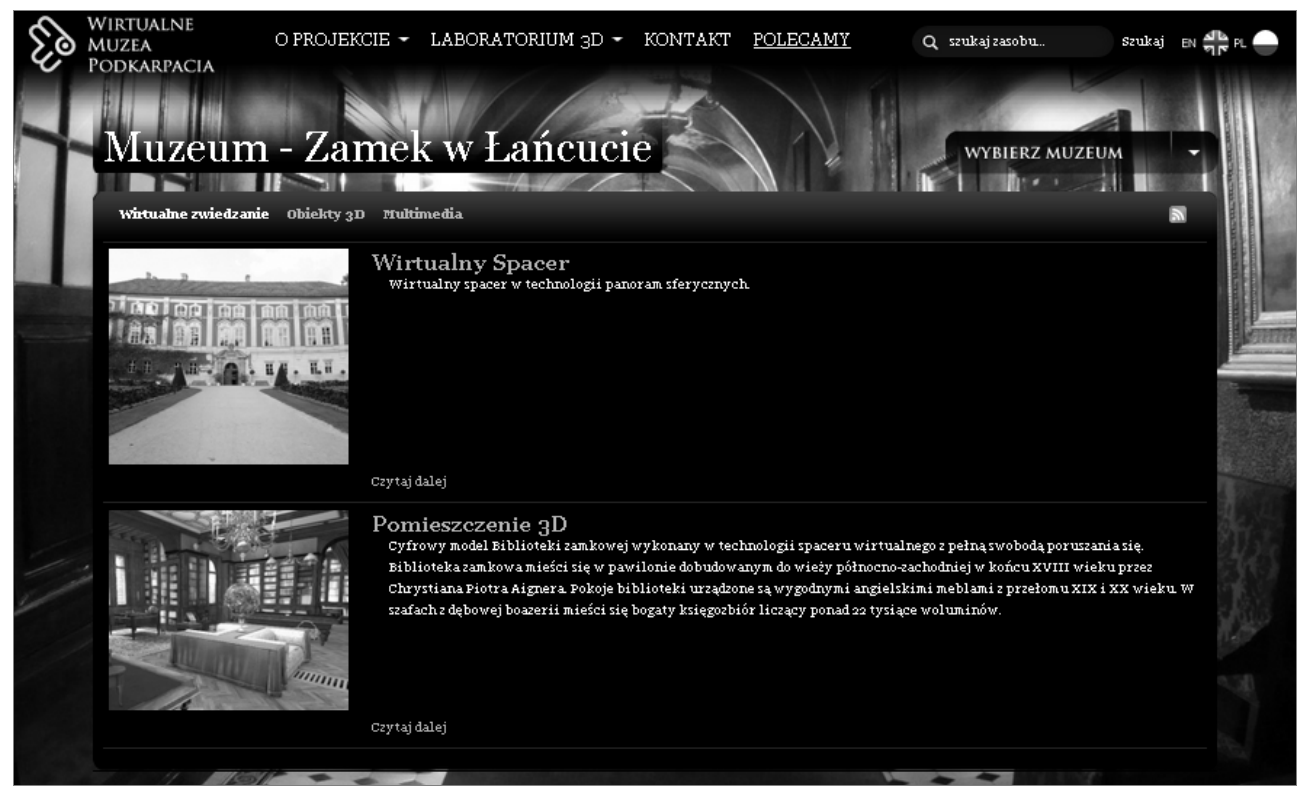

Rys. 7. Strona Wirtualnego Muzeum Podkarpacia pozwalająca na rozpoczęcie „zwiedzania” Zamku w Łańcucie

Źródło: www.wmp.podkarpackie.pl/taxonomy/term/423 (5.09.2012 r. )

W Internecie łatwo jest znaleźć wiele takich serwisów. Ilustracją z obszaru Polski może być np. „Wirtualny Spacer” po Zamku w Łańcucie (rys. 7). Wirtualne zwiedzanie oczywiście nie jest w stanie zastąpić bezpośredniego obcowania z zabytkami lub innymi obiektami o walorach turystycznych. Niemniej może stanowić sposób na zapoznanie się z miejscami, które zamierzamy odwiedzić w przyszłości czy takimi, do których nie dotrzemy nigdy (ze względu na odległość lub inne bariery - choćby finansowe). Dla okre- 
ślonych grup osób (chorych lub niepełnosprawnych) może być to także jedyna forma poznawania świata, niemożliwa do zrealizowania $w$ inny sposób. Wskazać należy także walor edukacyjny wirtualnych wycieczek, gdyż są one doskonałym uzupełnieniem wiedzy zdobywanej w szkole oraz przekazywanej przez inne media.

Szczególnym rozwinięciem wirtualnego zwiedzania jest realizowany w ostatnich latach projekt stanowiący usługę firmy Google o nazwie Street View. Jest to usługa powiązana z udostępnionymi już wcześniej w sieci usługami Google Maps i Google Earth. Wykorzystując specjalnie przystosowane samochody wyposażane w wiele kamer współpracownicy Google przejeżdżają ulicami miast lub po innych atrakcyjnych trasach. Nagrany w trakcie przejazdu film i wykonane zdjęcia, po dokonaniu obróbki komputerowej, udostępniane są $\mathrm{w}$ Internecie $\mathrm{w}$ powiązaniu $\mathrm{z}$ istniejącymi mapami i planami miast. Za pomocą odpowiedniego skryptu programowego działającego na stronach WWW użytkownicy Internetu mogą przemieszczać się po ulicach miast oglądając widoki zarejestrowane wcześniej kamerą.

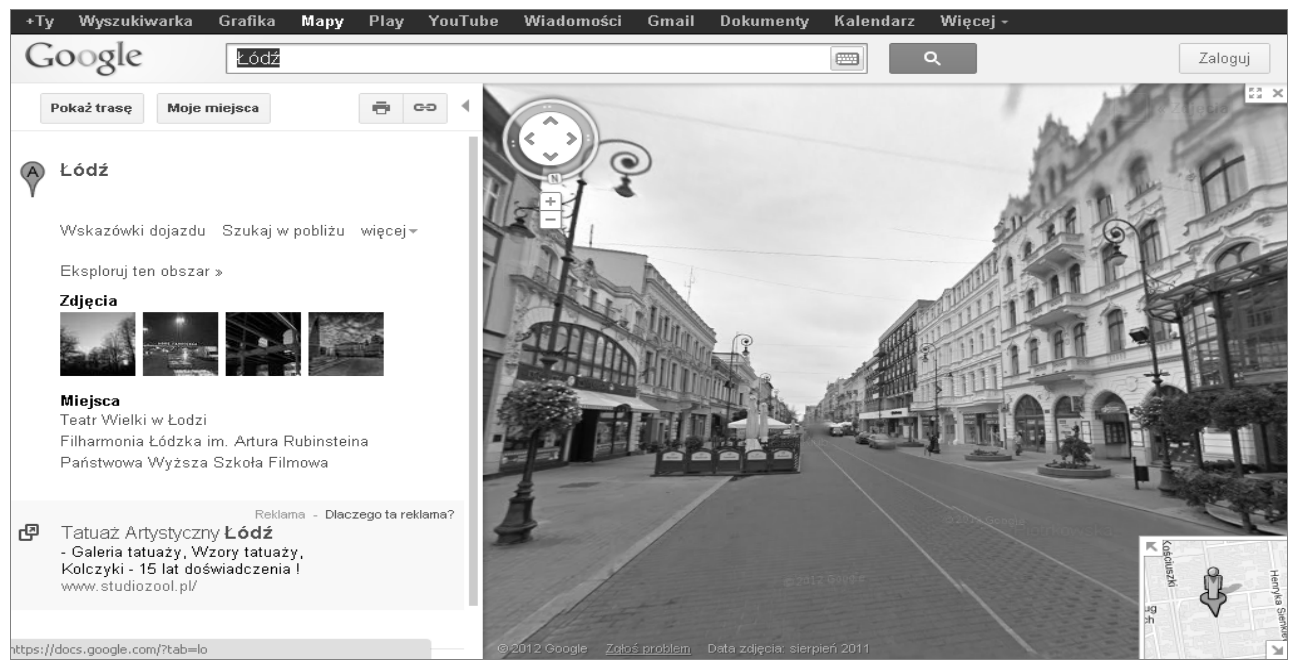

Rys. 8. Widok ulicy Piotrkowskiej w Łodzi w usłudze Google Street View Źródło: maps.google.pl

Widoki są panoramiczne, z możliwością przybliżania i oddalania obiektów oraz oglądania ich z różnych ujęć. W Polsce pierwszym miastem, które można było oglądać korzystając z usługi Street View była Łódź. Jako pier- 
wszy w dniu 23 marca 2012 r. udostępniony został obraz z ulicy Piotrkowskiej. Usługa rozwijała się bardzo szybko i w końcu roku 2012 dostępne były także widoki innych ulic $\mathrm{w}$ Łodzi oraz wielu innych miast $\mathrm{w}$ Polsce (rys. 8).

\section{QR Kody}

Kolejną z usług dostępnych dzięki Internetowi, która znalazła zastosowanie w dziedzinach związanych z turystyką jest QR Kody (określana też niekiedy jako Fotokody). Wyjaśniając najprościej, jest to rozwinięcie znanych i stosowanych powszechnie kodów kreskowych. W przypadku QR Kodów mamy do czynienia z zakodowaną informacją w postaci dwuwymiarowego obrazka - będącego mozaika punktów. Zanim usługa ta zaczęła być wykorzystywana w turystyce, już w połowie lat 90 . XX w. podobne kody stosowane były w Japonii do oznaczania części samochodowych. Dzięki odpowiedniemu algorytmowi kodowania informacji w jednym obrazku można zapisać do 7089 znaków, co odpowiada czterem stronom tekstu formatu A4. Mogą to być znaki należące do różnych alfabetów, a także zdefiniowane przez użytkownika (rys. 9).

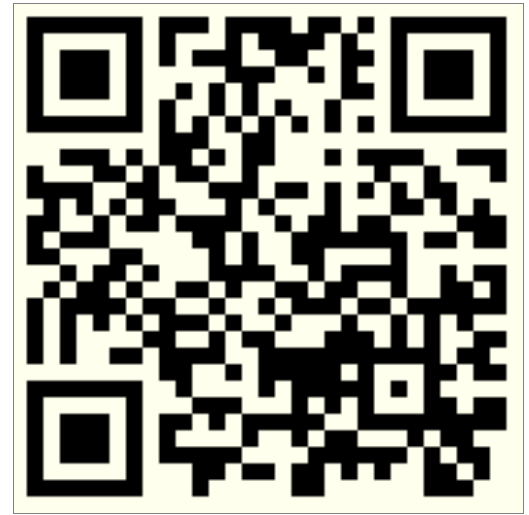

Rys. 9. Przykład informacji zapisanej za pomocą QR Kodu Źródło: mpoznan.pl (5.09.2012 r.) 
Rozwój mobilnego Internetu oraz telefonów komórkowych mogących odczytywać zakodowane informacje spowodował, że usługa ta znajduje obecnie zastosowanie $\mathrm{w}$ wielu dziedzinach życia. $\mathrm{W}$ najprostszym zastosowaniu użytkownik telefonu komórkowego może błyskawicznie wyświetlić na ekranie zakodowane informacje. W bardziej złożonych przypadkach $\mathrm{w}$ kodzie ukryty jest odnośnik do strony internetowej, z którą łączy się telefon użytkownika i stamtąd pobiera informacje wyświetlane na ekranie. W tym przypadku może być to zarówno tekst, jak i inne elementy występujące na typowych stronach WWW.

W Polsce QR kody do swoich katalogów jako pierwsze wprowadziło biuro Sky Club (rys. 10).

\section{INTERAKTYWNA OFERTA SKY CLUB DZIĘKI QR KODOM}

\section{- REDAKCJA (C) 22 LISTOPADA 2011 피 0}

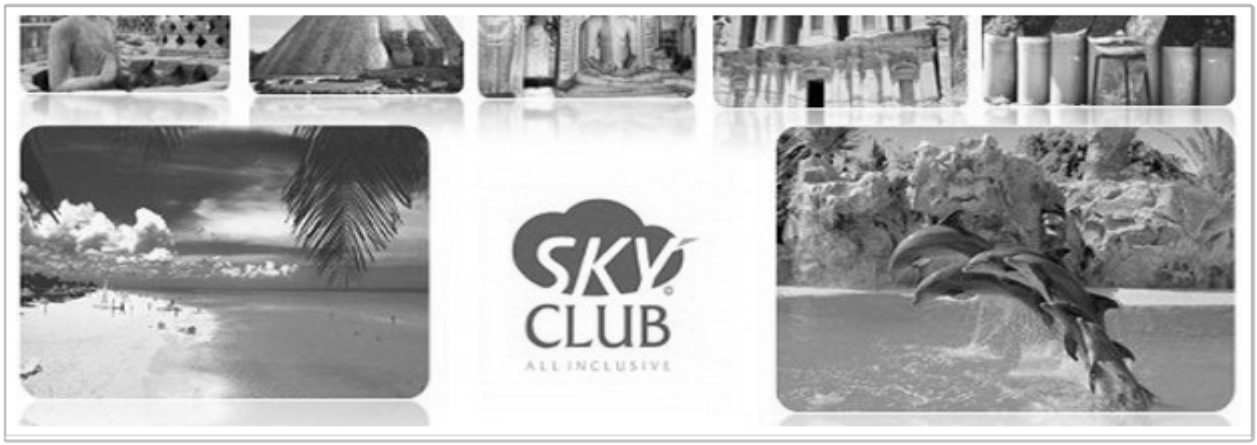

Biuro podróży Sky Club wprowadziło do swojego katalogu Lato 2012 innowacyjne rozwiązanie w postaci QR kodów. Umieszczone obok ofert wyjazdów znaki graficzne można zeskanować przy pomocy smartfona, uzyskując szczegółowe informacje o wybranej wycieczce.

Rys. 10. Informacja o zastosowaniu QR Kodów przez biuro Sky Club Źródło: xmobile.pl (5.09.2012 r.)

Dodatkowe informacje w postaci QR Kodów pojawiają się obecnie coraz częściej $\mathrm{w}$ reklamach i na plakatach promujących imprezy turystyczne. Ciekawą formą wykorzystania tej usługi, znaną w Japonii, a w Europie zastosowaną po raz pierwszy w Łodzi, jest opisywanie w ten sposób obiektów turystycznych. Dzięki stworzonemu w 2009 r. projektowi nazwanemu „Odkoduj Łódź", na 70 najważniejszych zabytkach w Łodzi, obok tradycyjnych 
tabliczek z tekstem, umieszczono QR Kody (rys. 11). Zabytki podzielono na grupy, wyznaczając w ten sposób trzy szlaki turystyczne. Zwiedzający Łódź, wyposażeni $\mathrm{w}$ telefon komórkowy mogą obecnie zapoznać się $\mathrm{z}$ wieloma dodatkowymi informacjami o danym obiekcie, korzystając z opisu w różnych językach lub wysłuchać informacji czytanych przez lektora. Dodatkowo zobaczyć można zdjęcia oraz filmy związane $\mathrm{z}$ danym zabytkiem. Dzięki Internetowi informacje mogą być cały czas wzbogacane bez konieczności wymiany tablic informacyjnych.

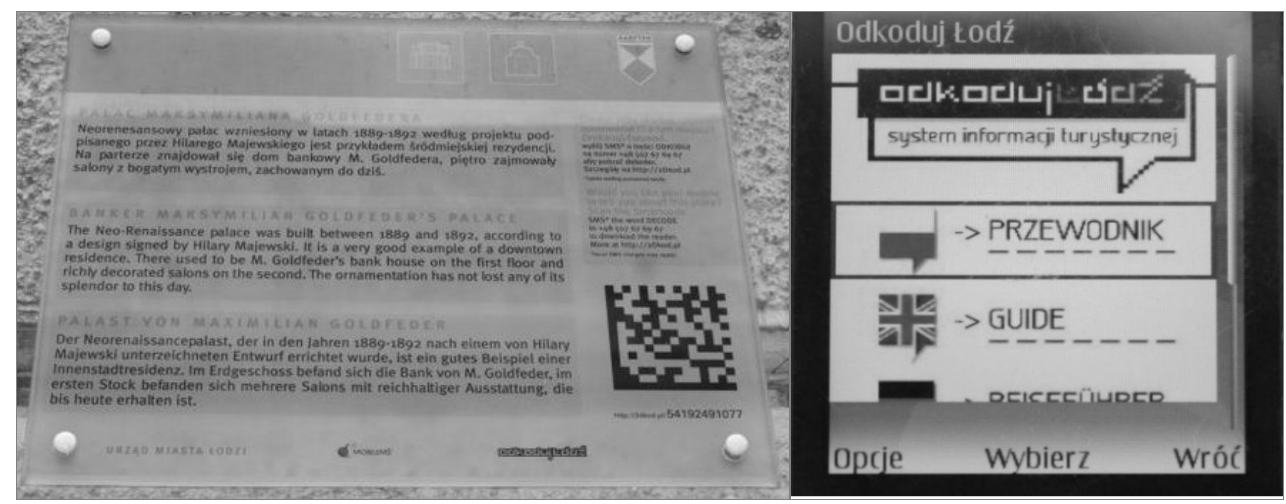

Rys. 11. Tabliczka z QR Kodem na pałacu Maksymiliana Goldfedera przy ulicy Piotrkowskiej 77 w Łodzi i widok aplikacji w telefonie komórkowym Źródło: www.odkodujlodz.pl (5.09.2012 r.)

Wykorzystując możliwości telefonów komórkowych i coraz powszechniejszego mobilnego dostępu do Internetu można znaleźć też nowe formy przewodników turystycznych. Przykładem może być polski produkt o nazwie YouGo Mobile - aplikacja działająca w smartfonach z systemem Android (rys. 12). Na podstawie bieżącej lokalizacji telefonu, określonej w oparciu o położenie nadajników telefonii komórkowej, aplikacja pokazuje na mapie najciekawsze obiekty warte zobaczenia. Użytkownik po wskazaniu któregoś $\mathrm{z}$ nich uzyskuje wiele informacji, które pobrane zostają $\mathrm{z}$ serwisu internetowego.

Pomysł jest dopiero w początkowej fazie rozwoju i liczba opisanych obiektów jest jeszcze niewielka. Jednak, o ile zyska zainteresowanie użytkowników, spodziewać się można jego szybkiego rozwoju. 


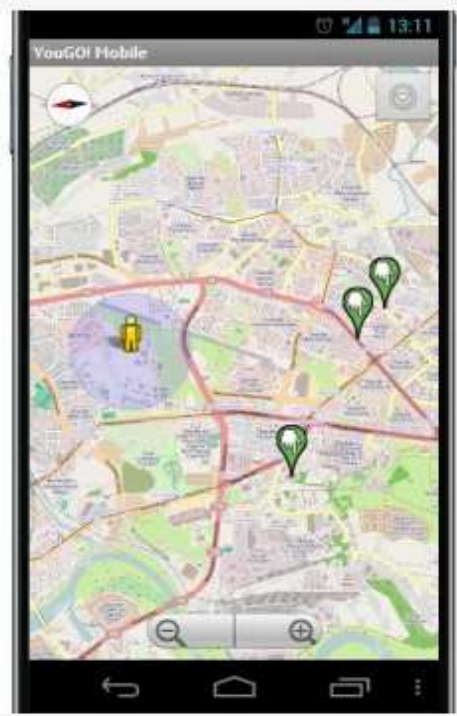

Pobierz przewodnik turystyczny

YouGO! Mobile za darmo

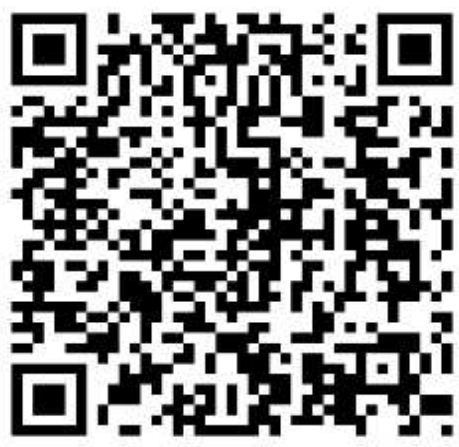

Rys. 12. Widok ekranu telefonu z aplikacją YouGo Mobil oraz QR Kod pozwalającą na pobranie przewodnika Źródło: yougo.pl (3.09.2012 r.)

\section{Rzeczywistość rozszerzona}

W chwili obecnej najbardziej zaawansowanym sposobem wykorzystującym Internet $\mathrm{w}$ dziedzinie turystyki jest technologia rzeczywistości rozszerzonej (ang. AR - Augmented Reality). Według definicji zaproponowanej przez Ronalda Azuma: „Rzeczywistość rozszerzona jest systemem łączącym w sobie świat realny oraz rzeczywistość wirtualną i interaktywność w czasie rzeczywistym, umożliwiającym swobodę ruchów w trzech wymiarach". Technologia ta polega na łączeniu obrazu świata rzeczywistego (najczęściej z kamery telefonu komórkowego) z elementami stworzonymi przy wykorzystaniu technologii informatycznej (obiekty 3D).

Poprzez użycie kamery w komórce i nakierowanie jej na określony obiekt ujęty w systemie, użytkownik może otrzymać dodatkowe fakty dotyczące historii, funkcji obiektu, a także wizualizacje tego, jak dany obiekt wyglądał w przeszłości lub będzie wyglądał w przyszłości. Baza obiektów, o których możemy uzyskać informacje jest cały czas poszerzana. Są to nie tylko zabytki 
i hotele, ale także sklepy, galerie, kina i teatry, restauracje, a także urzędy i instytucje. Dzięki takim możliwościom jesteśmy w stanie dotrzeć do każdego interesującego nas miejsca, nawet w kompletnie nieznanym mieście (rys. 13).

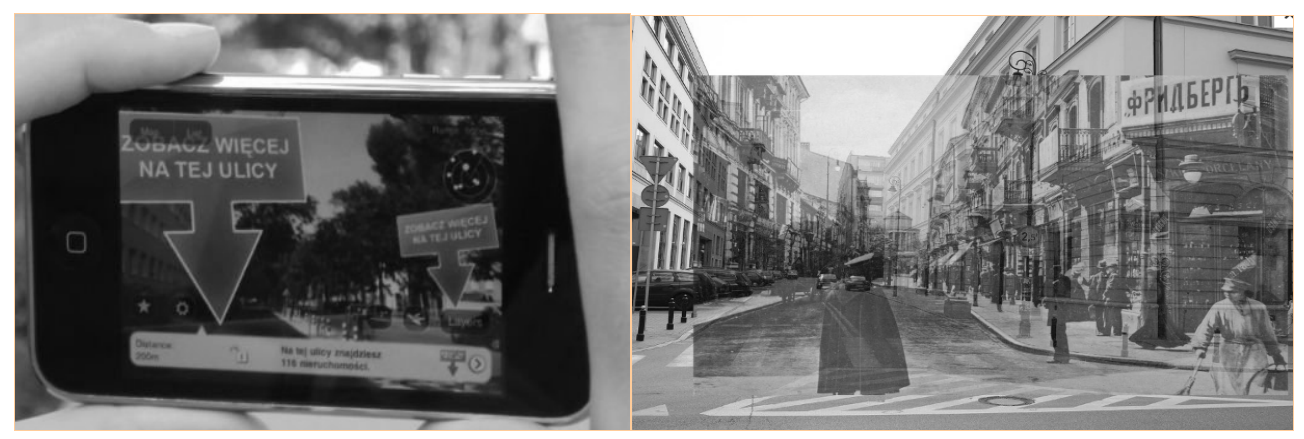

Rys. 13. Przykłady wykorzystania technologii rzeczywistości rozszerzonej Źródło: google.pl (5.09.2012 r.)

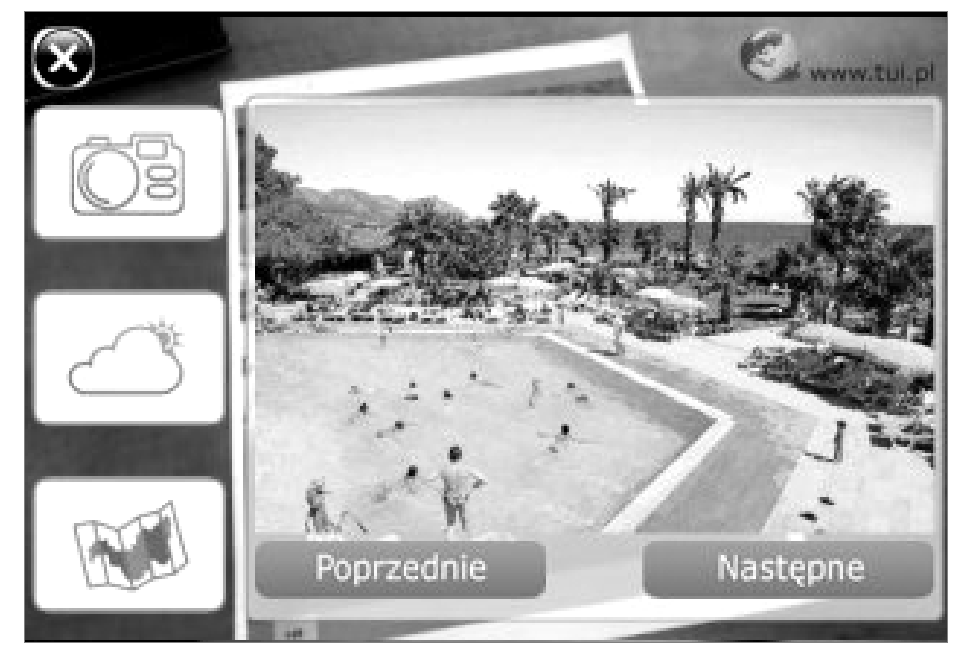

Rys. 14. Zastosowanie rzeczywistości rozszerzonej w katalogu TUI Polska Źródło: http://travel-fan.pl (5.09.2012 r.)

Rzeczywistość rozszerzoną zaczynają wykorzystywać także biura podróży w swoich katalogach z ofertami. Posiadając telefon komórkowy z odpowiednim oprogramowaniem możemy na publikowanych zdjęciach zobaczyć znacznie więcej niż dotychczas. Użytkownik ma możliwość wyświetlenia 
panoram, filmów i innych informacji związanych z danym obiektem lub miejscem. Dzięki interakcji za pośrednictwem Internetu można także dokonać rezerwacji lub zakupić daną usługę. W Polsce jednym z biur korzystających z tej technologii jest TUI Polska (rys. 14).

\section{Podsumowanie}

Technologie cyfrowe rozwijają się bardzo dynamicznie. Sprzyja temu coraz powszechniejszy dostęp do Internetu oraz nowoczesna telefonia komórkowa. Ich wykorzystanie $\mathrm{w}$ turystyce jest juz faktem $\mathrm{i}$ istniejących tendencji raczej już się nie zmieni. Należy spodziewać się powstawania coraz to nowszych rozwiązań zaawansowanych technologicznie, dostarczających turystom wszelkich możliwych informacji powiązanych z daną lokalizacją. Dzięki połączeniu możliwości GPS, mobilnego Internetu oraz różnorodnych baz danych już w tej chwili powstają zintegrowane systemy turystyczne, które nie tylko informują turystę o obiektach, ale także potrafią zaplanować trasę wycieczek (zmieniając jej przebieg w zależności od aktualnej sytuacji, np. pogodowej). Wkrótce to system będzie podpowiadał jak się ubrać, gdzie zaplanować odpoczynek i posiłek, które obiekty warto zwiedzić. Dzięki tego typu aplikacjom będzie można zarezerwować bilety wstępu, jak również przesłać bezpośrednio zdjęcia do portali społecznościowych. System też pomoże odszukać naszych znajomych będących w tej samej okolicy. Dzięki bieżącej lokalizacji każdego z turystów możliwy będzie także stały monitoring bezpieczeństwa na szlakach $\mathrm{i} \mathrm{w}$ razie konieczności wezwanie pomocy. $\mathrm{W}$ takich realiach spotkanie na szlaku kogoś z mapą i kompasem będzie wydarzeniem, o którym będzie się wspominać przez długi czas (podczas rozmów... na czacie). 